\title{
Coping with Student Teacher Stress at the University of Trinidad and Tobago
}

\author{
George Gowrie ${ }^{1}$, Mala Ramdass ${ }^{1}$, Vashti Singh ${ }^{1}$, Roland Birbal ${ }^{1}$, Cyril Harripaul ${ }^{1} \&$ Shaheeda Hosein $^{1}$ \\ ${ }^{1}$ The University of Trinidad and Tobago, Trinidad and Tobago \\ Correspondence: George Gowrie, The University of Trinidad and Tobago, Trinidad and Tobago.
}

Received: October 29, 2015

Accepted: November 17, $2015 \quad$ Online Published: November 20, 2015

doi:10.5430/irhe.v1n1p34

URL: http://dx.doi.org/10.5430/irhe.v1n1p34

\begin{abstract}
The study explored student-teachers' perceptions of the most common indicators of stress. It sought, also, to develop separate stress categories and make comparisons among them.

The sample consisted of randomly selected 306 student- teachers from two campuses of the University of Trinidad and Tobago - Valsayn and Corinth. There were thirty six males and 270 females in the study. The study examined the relationship between the student-teacher stress factors as well as the predictive power of each independent factor on overall teachers' stress.

The study employed a quantitative method using a cross-sectional design. The data were analyzed using the Statistical Package for the Social Sciences (SPSS-V.17). T-tests were used to examine teachers' stress based on location, sex and full or part time status. Correlation and regression analysis were employed to examine the relationship between each of the stress factors as well as their influence on the overall dependent teacher stress.

The findings suggested that there were no significant differences in teacher stress based on sex and location. There was a high correlation between professional development and curriculum-related stressors. Also, curriculum, personal/professional and professional development stressors had the greatest influence on overall student-stress.
\end{abstract}

Keywords: student - teacher, academic stress, the University of Trinidad and Tobago

\section{Background and Context}

Trinidad and Tobago, a twin-island state, is the most southerly of all the Caribbean islands. The island, after five centuries of foreign domination, gained its independence from Britain in 1962. The island possesses a British-oriented model of bureaucracy, which is reflected in the education system. Within the Trinidad and Tobago's education system, there are government schools, which are fully owned and operated by the state; government-assisted or denominational schools, which are managed by a private body( usually a religious denomination) but given financial assistance by the state; private schools, which are maintained and operated by private bodies without the assistance from the state; and special schools, which are designed for educating children with special needs and which provide education mainly at the primary level. Generally speaking the government-assisted schools are regarded as the better schools and there is a great demand for placement in these schools.

At the University of Trinidad and Tobago prospective teachers are exposed to a four-year Bachelor of Education Degree Program consisting of a wide range of content, professional and pedagogical courses and the practicum. The content courses over the four year period included Social Studies, Mathematics, Language, Visual and Creative Arts, Science, Agricultural Science, Spanish and Health and Family Life. The professional and pedagogical courses include Classroom Management, Classroom-based Assessment, Curriculum Studies, Contemporary Issues in Education and Instructional Design. The eight Practicum courses over the four years aim to provide student-teachers with opportunities to critically examine practical experiences of teaching and to develop and deepen their practical knowledge of teaching. This practical knowledge includes an understanding of the practical circumstances in which teachers work (personal practical knowledge), knowledge gained from classroom situations and the tasks of teaching (classroom knowledge), and knowledge of how to teach specific subject matter (pedagogical content knowledge). 


\section{Review of the Literature}

Stress can be defined as the experience of the unpleasant, negative emotions, such as anger, anxiety, tension, frustration, and depression resulting from some aspect of their work as a teacher (Kyriacou, 2001).

The study was guided by a range of theories and models such as the social-ecological (Bronfenbrenner, 1977), social cognitive (Bandura, 2001), the transactional model of stress (Lazarus \& Folkman, 1984), psychological distress (Mirowsky \& Ross, 2003), motivational (Herzberg, Mausner \& Synderman, 1959), and the demand-control model (Ganster and Perrewe, 2011).

The social-ecological theory is a systems approach that emphasizes the complex environmental system where people live and operate and carefully defines the multi-layered environment in which individual actions occur. Bronfenbrenner (1977) depicts the environment through four unique subsystems each one nested within the other. The first subsystem is the micro-system which is the immediate classroom where the teacher works and carries out the majority of his or her activities. At this level a major component of stress is teacher workload. Teachers' workloads include a vast array of tasks that are not limited to instruction, such as learning new teaching approaches, keeping current of technological innovations, student behavior problems, staff meetings and parent/school commitments. Butt and Lance (2005) found that teachers named the most excessive workload concerns associated with non classroom tasks that take over their personal lives, especially those related to teacher accountability. The second subsystem is the meso- system which is the school, the third system is the exo-system which is the community in which the teacher operates, and the final system is the macro-system the larger school districts, the nation and the various laws and regulations that govern teaching. This approach allows for interactions between the individual and each subsystem and for interactions between subsystems to be studied. This systems approach defines the different components that make up the school environment. To study teachers effectively, the complex environment in which they work must be taken into account and carefully analyzed. Moreover, because teacher stress and dissatisfaction is a complex phenomena with a myriad of causes, each subsystem should be considered carefully for its particular influence, be it directly or indirectly through another source such as teacher efficacy or burnout. According to Bronfenbrenner, each layer, such as the classroom, the school, the community and the country contribute to the overall environment where teachers experience satisfaction or dissatisfaction. Indeed, the socio-ecological theory is useful in explaining how the school environment can be related to teacher stress in terms of the afore-mentioned environmental factors.

Bronfenbrenner's social-ecological theory has been applied to the study of teachers. For example, Miller, Bronwell and Smith, (1999) used this theory to highlight teacher dissatisfaction among special education to predict teachers staying in, leaving, or transferring from special education.

Bandura's social cognitive theory (Bandura, 2001) addresses the human aspect of the school system and the dignity of teachers that could lead to greater job satisfaction and increased school productivity. Bandura proposed that there were four general sources of efficacy building information: verbal expression, vicarious experiences, psychological arousal and mastery experiences (Bandura, 1977). According to Bandura, efficacy beliefs are explicitly self-referent in nature and directed toward perceived abilities, given specific tasks, and were powerful predictors of behavior (Bandura, 2001). Bandura argued that human behavior is influenced by the individual's beliefs regarding two classes of expectations: an outcome expectation, 'a person's estimate that a given behavior will lead to certain outcomes,' and an efficiency expectation, 'the conviction that one can successfully execute the behavior required to produce an outcome'. Bandura further noted that teachers who have a high sense of efficacy visualize scenarios that provide positive guides and support for performance (Bandura, 1993). Indeed, Bandura's theory demonstrates that self efficacy is very important in order for teachers to be able to cope effectively with the demands of teaching. If teachers have confidence in themselves and their ability to deal with challenging tasks, self- efficacy can act as a protective factor against teacher stress and burnout. Numerous studies on teacher efficacy (Pajares, 1996; Sewell and St. George, 2000; Goddard, Hoy and Hoy, 2000) have underscored the importance of a positive school environment that helps to reduce stress among both students and teachers.

Another potentially powerful paradigm for better understanding stress and coping is the transactional model proposed by Lazarus and Folkman, (1984). They suggested that when a person encounters life demands, a cognitive process is triggered in which perceived demands of the event are weighted against a person's perceived capabilities for coping with these demands. When this transaction results in a perception that one is facing demands that exceed the resources one has for coping the stress response ensues. Prospective and experienced teachers who experience excessive demands vis-a-vis their resources are at risk for the negative effects of stress, which can include health problems and burnout (Sapolsky, 1998). Using the transactional model of stress McCarthy \& Lambert (2006) examined levels of elementary teachers' burnout symptoms and their personal resources and experience from a 
sample of 481 teachers and 13 schools. Their findings supported the transactional model as individual differences among teachers within schools in perceptions of demands and resources were predictive of burnout symptoms. Additional studies have also found that stress symptoms occur when perceived demands exceed perceived resources (Kyriacou, 2001).

The theory of psychological distress (Mirowsky \& Ross, 2003) is also pertinent in getting a firmer grasp in understanding stress. According to Mirowsky and Ross, psychological distress can take two forms: depression and anxiety. Teachers encounter many potential negative events in their everyday professional lives over which they have little or no control or power. Students' behaviours and lives outside the school, school board, and government initiatives, job security and promotion are just a few examples of situations which can become distressful to teachers (Cedoline, 1982).

The theory of motivation, as espoused by Herzberg, Mausner, \& Synderman, (1959), has significantly contributed to a better understanding of the motivating forces that enhance job satisfaction. Their Motivation-Hygiene Theory makes a distinction between two sets of job factors. One set is related to the actual doing of the job, or the intrinsic aspects of the job. These factors are called 'motivators' which produce satisfaction and include: achievement recognition, work itself, responsibility and advancement. The other set of job factors is related to the environmental setting or extrinsic factors of the job. These factors are termed 'hygiene' and include: policy and administration, supervision, salary, status and security. The lack of 'hygiene' factors produce dissatisfaction. According to Herzberg et al highly motivated and satisfied teachers can create a healthy, social, psychological and physical climate of the school.

According to the demand-control model, a psychological work environment can be characterized by job demands and job control decisions. Job control refers to a person's ability to control his or her work activities to make decisions on the job. Job demands refer to the task requirements and include constructs such as time pressure or role conflicts (van der Doef \& Maes, 1999). One recent research study examined the relevance of the Demand-Control Model for explaining stress and students' satisfaction among psychology students in Germany. The study found that high demands were the main predictor of students' stress and low decision latitude was the main predictor of low student satisfaction (Schmidt, Sieverding, Scheiteiter \& Obergfell, 2013).

Other stress studies focused on the experiences of stress among students following different university courses. Abouserie (1994), for example, investigated sources and levels of stress among second-year students at the University of Wales. He found that students were most affected by stressors related to assessment and examination results. Similar studies (Ross, Niebling \& Heckert, 1999) examined the interpersonal, academic and environmental sources of stress. The study concluded that the main stressors were change in sleeping habits and increased work load. Other supportive stress-related studies (Towbes \& Cohen, 1996) focused on chronic stress in the lives of college students. The studies found that first-year students scored higher with regard to chronic stress than other students.

In other empirical literature Perrachione, Rosser and Peterson (2008) attempted to identify intrinsic and extrinsic variables that influence job satisfaction among prospective and elementary teachers. Their findings suggested three intrinsic motivators (job satisfaction, personal teaching efficacy, and working with others) were perceived to significantly influence satisfaction and retention, while the extrinsic motivator (increased workload) did not have any significant effect. Further research by Dinham and Scott (2000) has suggested that job satisfaction is thought to be connected to factors associated with intrinsic rewards (student-teacher relationship, and student achievement) while teacher dissatisfaction is linked more closely with extrinsic factors (school leadership, work load and communication). Further research by Skaalvik and Skaalvik (2011) found six variables: value consonance, supervisory support, relations with colleagues, relations with parents time pressure and discipline problems were related to job satisfaction and motivation. Other research studies have examined the relationship between job satisfaction and teacher-related stress. These studies found working conditions, employment conditions, professional challenge, reward and control over work were strong predictors of stress (Decker, 1997; Flanagan, 2006; Rout, 2000).

\section{Research Questions}

The following research questions guided the study:

1. Which stress factors affect student teachers most at the University of Trinidad and Tobago?

2. Were there differences in each of the student- teacher stress factors based on sex, location and full or part-time status?

3. What was the relationship between the six student-teachers stress factors? 
4. Which student-teacher stress factors had the strongest relationship to overall teacher stress?

\section{Research Methodology}

The study was quantitative using a cross-sectional design. Such a design was considered appropriate since was it exploratory and a large sample of schools and teachers participated in the study.

The sample consisted of 306 student- teachers from the Valsayn and Corinth campuses of the University of Trinidad and Tobago. These student teachers were randomly chosen from the first and fourth year cohorts. The sample consisted of thirty six males and 270 female student-teachers. These student-teachers are pre-service and have not been previously exposed to any formal classroom teaching.

\subsection{Questionnaire Description and Validity}

The student teacher stress questionnaire used in the study was based on the Academic Stress Scales developed by Kohn and Frazer (1986) and Balaj Rao (2013), and the Student Stress Survey (Ross, Niebling and Heckert (1999). The researchers identified an initial 85 stress items. Principal Component Analysis with varimax rotation was performed and the number of stressors were reduced to 56 items and six stress Factors (Table 1). The final questionnaire consisted of 56 items that were divided into 6 Factors of potential sources of student teacher stress: 9 items representing professional development stressors, 17 items representing curriculum and instruction stressors, 7 items representing teamwork stressors, 3 items representing assessment stressors, 12 items representing personal/psychological stressors, and 8 items representing practicum stressors. Professional development related stressors involved, inter-alia, too much demands on students, lack of communication between lecturers and students and lecturers lack of interest in students; curriculum and instruction stressors included overloaded content, inadequate subject knowledge of lecturers in some areas, and incomplete and confusing study material. Curriculum-related stress items include lack of varied teaching strategies, inadequate teaching facilities, confusing study material and monotonous teaching style. Teamwork related stressors involved problems communicating with the group, lack of mutual help among students, and poor inter-personal relations. Assessment-related stressors included too many assignments in some areas, lack of clarity of assessment and poorly designed assessment. Personal/psychological-related stressors involved lack of self confidence, pressure to perform well in exams and balancing home and university. Practicum-related stressors include not enough exposure in classroom practice, too much content and pedagogy and lack of mentorship from practicum advisors (Table 1).

Table 1. Loadings of the 5-Factor solution principal component analysis result

\begin{tabular}{|c|c|c|c|c|c|c|}
\hline \multirow[t]{2}{*}{ Statements } & \multicolumn{6}{|c|}{ Factors } \\
\hline & 1 & 2 & 3 & 4 & 5 & 6 \\
\hline \multicolumn{7}{|l|}{ Factor 1 Professional Development (9) } \\
\hline Lecturers lack interest in students & .734 & & & & & \\
\hline $\begin{array}{l}\text { Lack of communication between lecturers } \\
\text { and students }\end{array}$ & .791 & & & & & \\
\hline Lack of opportunity to meet lecturers & .748 & & & & & \\
\hline Biased attitude by lecturers & .760 & & & & & \\
\hline Too much extra demands on students & .657 & & & & & \\
\hline Lecturers do not listen to students & .828 & & & & & \\
\hline Hesitate to ask for detailed explanation & .668 & & & & & \\
\hline Unable to discuss failure & .673 & & & & & \\
\hline Relationships with some lecturers & .673 & & & & & \\
\hline \multicolumn{7}{|l|}{ Factor 2 Curriculum (17) } \\
\hline Not enough discussion in class & & .561 & & & & \\
\hline Monotonous teaching style & & .554 & & & & \\
\hline Inadequate lab/teaching facilities & & .665 & & & & \\
\hline $\begin{array}{l}\text { Inadequate subject knowledge of lecturers } \\
\text { in some areas }\end{array}$ & & .645 & & & & \\
\hline $\begin{array}{l}\text { Examination syllabus too heavy in some } \\
\text { areas }\end{array}$ & & .702 & & & & \\
\hline $\begin{array}{l}\text { Unable to grasp subject matter in some } \\
\text { areas }\end{array}$ & & .682 & & & & \\
\hline Incomplete and confusing study material & & .757 & & & & \\
\hline
\end{tabular}


Eleventh hour preparation for exam $\quad .653$

Contribution to class discussion $\quad .441$

Attending classes regularly $\quad .364$

Completing individual assignments on $\quad .481$

time

Spending lot of extra time studying $\quad .459$

Getting exam results too long $\quad .446$

Lack of varied teaching strategies $\quad .687$

Inadequate resources at University $\quad .665$

Too many changes in curriculum $\quad .686$

Too much course work demands in some $\quad .627$

areas

Factor 3 Teamwork (7)

Lack of mutual help among students $\quad .449$

Problems adjusting to group mindset $\quad .708$

Relations with others not satisfactory $\quad .712$

Hesitate meeting with others $\quad .746$

Problems communicating with group $\quad .764$

members

Making joint presentations is stressful $\quad .734$

Difficulty completing group assignments $\quad .721$

on time

\section{Factor 4 Assessment (3)}

Too many test/assignments in some areas $\quad .769$

Lack of clarity of assessments in some $\quad .867$

areas

Assessment not well designed in some

areas

Factor 5 Personal/Psychological (12)

Worry about results

Lack of self confidence

Difficulty remembering study material

Not knowing how to prepare for exam

Feeling of inferiority

Difficulty in adjusting to opposite sex

Unable to concentrate on studies

Excited very easily

Problems keeping up with assignments

Balancing home and University

Pressure to perform well in exams

Lack of opportunity to develop

Factor 6 Practicum (8)

Mentorship support from practicum

advisors

Feedback from practicum advisors

Guidance from cooperating teachers

Too much time on planning and in-house

seminars

Not enough exposure in classroom

practice

Little link between theory and practice

Too much content and pedagogy

Lack of coherence of pedagogy of

practicum 
The Cronbach Alpha was further used to test the reliability of the questionnaire (Table 2).

Table 2. Number of items and Cronbach's Alpha Coefficient of the six stress factors

\begin{tabular}{lll}
\hline Stress Factors & Number of Items & Cronbach Alpha \\
\hline Professional development & 9 & .888 \\
\hline Curriculum & 17 & .886 \\
\hline Teamwork & 7 & .879 \\
\hline Assessment & 3 & .766 \\
\hline Personal/Psychological & 12 & .867 \\
\hline Practicum & 8 & .884 \\
\hline
\end{tabular}

\subsection{Data Analysis and Interpretation}

A total of 306 questionnaires were analyzed using an up-dated version of the Statistical Package for Social Scientists with a recent guide. A 1-2-3-4-5 Likert Scale was used to arrive at numerical values for use in the data analysis. Since the unit of analysis was the school means were used in the data analysis. The following were the research questions that were quantitatively analyzed.

\section{Findings}

5.1 Research question 1: Which student teacher stress factors teachers perceived as affecting them the most?

This research question used factor and item means and frequencies to ascertain the importance teachers placed on each teacher stress factor. Factor means and the corresponding item means for each factor were computed. The importance teachers placed on each teacher stress factor ranged from 1.00 to 5.00, 1.00 being the lowest and 5.00 the highest value. There were five interval ranges: 1.00 to $2.00,2.01$ to $3.00,3.01$ to $4.00,4.01$ to 5.00 to arrive at the importance on each of the four teacher stress factor. The teacher stress items means associated with each factor were arranged across the total sample to represent each factor.

This research question used descriptive statistics to ascertain which stress factors students perceived as affecting them the most. The means and standard deviations were used for comparison. Of the six stress factors student teachers rated assessment $(\mathrm{M}=3.46)$ followed by curriculum $(\mathrm{M}=2.86)$ and professional development $(\mathrm{M}=2.74)$ as the highest stress-related factors. Team work and the practicum was viewed as the least important stressors (Table 3).

Table 3. Teacher stress factors: Scale Mean, $\mathrm{N}$ and standard deviation

\begin{tabular}{llll}
\hline Teacher Stress Factors & $\mathrm{N}$ & Mean & SD \\
\hline Professional Development & 306 & 2.74 & .949 \\
\hline Curriculum & 306 & 2.86 & .746 \\
\hline Team work & 306 & 2.64 & .861 \\
\hline Assessment & 306 & 3.46 & 1.00 \\
\hline Personal/Psychological & 306 & 2.69 & .781 \\
\hline Practicum & 306 & 2.49 & .955 \\
\hline
\end{tabular}

5.2 Research Question 2: Were there differences between (i) student teachers from Corinth and Valsayn Campuses (ii) male and female student teachers (iii) full-time and part-time and (iv) Year One and Year Four students on each of the six stress factors?

\section{2(i) Differences based on location}

With regard to significant differences based on location the study found that there were no significant differences between teachers on each of the stress factors in Valsayn and Corinth Campuses (Table 4). Table 4 shows means and standard deviations and t-test results for each of the six dimensions of student-teacher stress. At the 0.05 probability 
level there were no statistically significant difference between the Valsayn and Corinth Campuses on all six dimensions of student teacher stress.

Table 4. T-test results comparing Valsayn and Corinth campuses

$\begin{array}{clcccc}\text { Factor } & \text { Location } & \mathrm{N} & \text { Mean } & \text { SD } & \text { Significance } \\ & & & & & \\ \text { Professional } & \text { Valsayn } & 207 & 2.70 & .983 & .169 \\ & \text { Corinth } & 99 & 2.83 & .871 & \\ \text { Curriculum } & \text { Valsayn } & 207 & 2.85 & .796 & .108 \\ & \text { Corinth } & 99 & 2.88 & .633 & \\ \text { Teamwork } & \text { Valsayn } & 207 & 2.69 & .851 & .511 \\ & \text { Corinth } & 99 & 2.54 & .880 & \\ \text { Assessment } & \text { Valsayn } & 207 & 3.40 & 1.03 & .171 \\ & \text { Corinth } & 99 & 3.57 & .936 & .599 \\ \text { Personal } & \text { Valsayn } & 207 & 2.73 & .778 & \\ & \text { Corinth } & 99 & 2.63 & .784 & \\ \text { Practicum } & \text { Valsayn } & 207 & 2.48 & .972 & \\ & \text { Corinth } & 99 & 2.50 & .924 & \\ & & & & & \end{array}$

\section{2(ii) Differences based on sex}

Table 5 shows means, standard deviation and t-test results for each of the six dimensions of student teacher stress. At the 0.05 probability level there were no statistically significant difference between male and female student teachers on all six dimensions of student teacher stress (Table 5).

Table 5. T-test results comparing male and female student teachers

$\begin{array}{llllll}\text { Factor } & \text { sex } & \text { N } & \text { Mean } & \text { SD } & \text { Sig } \\ \text { Professional } & \text { Male } & 36 & 2.44 & .861 & .610 \\ & \text { Female } & 270 & 2.78 & .955 & \\ \text { Curriculum } & \text { Male } & 36 & 2.63 & .862 & .113 \\ & \text { Female } & 270 & 2.89 & .726 & \\ \text { Teamwork } & \text { Male } & 36 & 2.32 & .784 & .330 \\ & \text { Female } & 270 & 2.68 & .864 & \\ \text { Assessment } & \text { Male } & 36 & 3.12 & 1.13 & .227 \\ & \text { Female } & 270 & 3.50 & .979 & \\ \text { Personal } & \text { Male } & 36 & 2.47 & .767 & .941 \\ & \text { Female } & 270 & 2.73 & .779 & \\ \text { Practicum } & \text { Male } & 36 & 2.27 & .954 & \\ & \text { Female } & 270 & 2.51 & .53 & \\ <0.05 & & & & & \end{array}$




\section{2( iii) Full- Time and Part-Time Students}

Table 6 shows means, standard deviation and t-test results for each of the six dimensions of student teacher stress. At the 0.05 probability level there was a statistically significant difference between full- time and part-time students on only the assessment related dimension of student teacher stress.

Table 6. T-test results comparing full-time and part-time students

$\begin{array}{llllll}\text { Factor } & \text { Status } & \mathrm{N} & \text { Mean } & \text { SD } & \text { Sig } \\ \text { Professional } & \text { Full Time } & 218 & 2.68 & .945 & .999 \\ & \text { Part Time } & 88 & 2.89 & .950 & \\ \text { Curriculum } & \text { Full Time } & 218 & 2.80 & .715 & .509 \\ & \text { Part Time } & 88 & 3.03 & .798 & \\ \text { Teamwork } & \text { Full Time } & 218 & 2.62 & .890 & .101 \\ & \text { Part Time } & 88 & 2.69 & .791 & \\ \text { Assessment } & \text { Full Time } & 218 & 3.42 & .963 & .039^{*} \\ & \text { Part Time } & 88 & 3.54 & 1.10 & .459 \\ \text { Personal } & \text { Full Time } & 218 & 2.64 & .790 & .323 \\ & \text { Part Time } & 88 & 2.84 & .742 & \\ \text { Practicum } & \text { Full Time } & 218 & 2.41 & .945 & \\ & \text { Part Time } & 88 & 2.67 & .961 & \end{array}$

\section{2 (iv) Year One and Year Four Students}

Table (7) shows means, standard deviation and t-test results for each of the six dimensions of student teacher stress. At the 0.05 probability level there were no statistically significant difference between the first year and final year (Year 4) student teachers on all six dimensions of student teacher stress.

Table 7. T-test results comparing Year One and Year Four students

\begin{tabular}{llllll}
\hline Factor & Status & $\mathrm{N}$ & Mean & SD & Sig. \\
\hline Professional & Year One & 205 & 2.59 & .936 & .402 \\
& Year Four & 101 & 3.03 & .911 & .621 \\
\hline Curriculum & Year One & 205 & 2.76 & .737 & .723 \\
& Year Four & 101 & 3.07 & .737 \\
\hline Teamwork & Year One & 205 & 2.66 & .833 & .241 \\
& Year Four & 101 & 2.60 & .921 & .284 \\
\hline Assessment & Year One & 205 & 3.33 & 1.02 & \\
& Year Four & 101 & 3.72 & .918 & \\
\hline Personal & Year One & 205 & 2.67 & .747 & .845 \\
& Year Four & 101 & 2.77 & .938 & \\
\hline \multirow{2}{*}{ Practicum } & Year One & 205 & 2.37 & .947 & \\
& Year Four & 101 & 2.73 & & \\
\hline
\end{tabular}

$* \mathrm{p}<0.05$ 
5.3 Research Question Four: What Was the Relationship between Each of the Student Teacher Stress Factors?

The Pearson Moment Correlation was the statistical technique used to measure the degree of relationship between the six teacher stress factors. There was a strong positive relationship between Factor 1 (professional development) and Factor 2 (curriculum) $(\mathrm{r}=0.776, \mathrm{p}<0.05)$, Factor 2 (curriculum) and Factor 4 (assessment) $(\mathrm{r}=0.758, \mathrm{p}<0.05)$, and Factor 2 (curriculum) and Factor 5 (personal/psychological) $(\mathrm{r}=0.796, \mathrm{p}<0.05)$. the relationship between Factor 3 (teamwork) and Factor 5 (personal/psychological) was moderate $(\mathrm{r}=0.602, \mathrm{p}<0.05)$ (Table 8$)$.

Table 8. Pearson Moment Correlation among the student-teacher stress factors

\begin{tabular}{lcccccc}
\hline Stress Factors & $\begin{array}{l}\text { Professional } \\
\text { Development }\end{array}$ & Curriculum & Teamwork & Assessment & $\begin{array}{l}\text { Personal/ } \\
\text { Psychological }\end{array}$ & Practicum \\
\hline Professional & 1 & $.776^{*}$ & $.458^{*}$ & $.633^{*}$ & $.623^{*}$ & $.628^{*}$ \\
Development & & .000 & .000 & .000 & .000 & .000 \\
Curriculum & & 1 & $.549^{*}$ & $.758^{*}$ & $.796^{*}$ & $.701^{*}$ \\
& & & .000 & .000 & .000 & .000 \\
Teamwork & & 1 & $.434^{*}$ & $.602^{*}$ & $.432^{*}$ \\
& & & .000 & .000 & .000 \\
Assessment & & & 1 & $.508^{*}$ & $.543^{*}$ \\
& & & & & .000 & .000 \\
Personal/ & & & & & $.622^{*}$ \\
Psychological & & & & & & .000 \\
Practicum & & & & & & 1 \\
\hline
\end{tabular}

$* \mathrm{p}<0.05$

\subsection{Research Question 5: Which Stress Factors Had the Greatest Influence on Overall Student Teacher Stress?}

Regression analysis was employed to examine the greatest influence on overall student teacher stress. Curriculum appeared to have the strongest influence on overall student-teacher stress $(\beta=.318)$, followed by Personal/Psychological $(\beta=.235)$, and Professional Development $(\beta=.214)$. The weakest influence was Assessment $(\beta=.075)$, followed by Teamwork $(\beta=.151)$ and Practicum $(\beta=.191)$ (Table 9$)$.

Table 9. R, R Square, adjusted R Square, Beta and significance

\begin{tabular}{|c|c|c|c|c|c|}
\hline Factor & $\mathrm{R}$ & R Square & $\begin{array}{l}\text { Adjusted } \\
\text { Square }\end{array}$ & R Beta & Sig \\
\hline $\begin{array}{l}\text { Professional } \\
\text { Development }\end{array}$ & .874 & .764 & .757 & .214 & $.000 *$ \\
\hline Curriculum & .954 & .910 & .905 & .318 & $.000^{*}$ \\
\hline Teamwork & .725 & .526 & .515 & .151 & $.000 *$ \\
\hline Assessment & .767 & .588 & .584 & .075 & $.000^{*}$ \\
\hline $\begin{array}{l}\text { Personal/ } \\
\text { Psychological }\end{array}$ & .892 & .795 & .786 & .235 & $.000 *$ \\
\hline Practicum & .813 & .660 & .651 & 191 & $.000^{*}$ \\
\hline
\end{tabular}




\section{Findings and Conclusions}

This was an exploratory study of student teachers' perceptions of stress at the University of Trinidad and Tobago and represents a first step in understanding sources of stress in the lives of students. The findings suggested that there was a strong correlation between professional development, curriculum and assessment-related stressors The sampled student teachers were of the view that assessment, followed by curriculum and professional development affected them the most. Some student-stress researchers have noted that assessment, curriculum and the implementation of new initiatives may add to a feeling of anxiety and stress especially among beginning teachers (Miller \& Fraser, 2000; Mirowsky \& Ross 2003). Practicum advisors need to pay more attention to student-teachers concerns, especially with regard to assignment overload, and lack of clarity of assignments.

In relation to professional development-related stressors such as lack of interest and biased attitude by some practicum advisors as well as student-teacher and practicum advisors relationship there ought to have more professional development seminars to deal with these important issues.

Indeed, the results of this stress study have significant implications for all stakeholders in education. Issues such as types of assessment, professional development issues and curriculum overload must be urgently addressed to help reduce stress and by extension increase job satisfaction. Further research on the relationship between job satisfaction and student teachers stress needs to be undertaken as increased motivation and job satisfaction would improve student teachers' quality of work life and contribute to more positive student outcomes. Additionally, research should expand on these findings by determining the degree of stress resulting from each source. Such research would permit conclusions on which stressors are most detrimental or severe and which stressors have a negligible influence. This information could be useful in designing stress intervention strategies and professional development workshops for student teachers.

\section{References}

Abouserie, R. (1994). Sources and levels of stress in relation to locus of control and self esteem in university students. Educational Psychology, 14(3), 323-30. http://dx.doi.org/10.1080/0144341940140306

Balaj, Rao. (2013). A study of academic stress and adjustment styles of teacher trainers. Department of Education, Acharya Nagarjuna University. Retrieved from http://hdl.handle/10603/8093

Bandura, A. (1977). Self-efficacy: toward a unifying theory of behavioural change. Psychology Review, 84(2), 191-215. http://dx.doi.org/10.1037/0033-295X.84.2.191

Bandura, A. (1993). Perceived self-efficacy in cognitive development and functioning. Educational Psychologist, 28(2), 117-48. http://dx.doi.org/10.1207/s153226985ep2802_3

Bandura, A. (2001). Social cognitive theory: an agentic perspective. Annual Review of Psychology, 52, 1-26. http://dx.doi.org/10.1146/annurev.psych.52.1.1

Bronfenbrenner, U. (1977). Toward an experimental ecology of human development. American Psychologist, 32(7), 513-531. http://dx.doi.org/10.1037/0003-066X.32.7.513

Butt, G., \& Lance, A. (2005). Secondary teacher workload and job satisfaction: do successful strategies for change exist? Educational Management, Administration and Leadership, 33(4), 401-22. http://dx.doi.org/10.1177/1741143205056304

Cedoline, A. J. (1982). Job burnout in public education: symptoms, causes and survival skills. New York, NY: Teachers' College Press.

Decker, F. H. (1997). Occupational and non-occupational factors in job satisfaction and psychological distress among nurses. Research in Nursing and Health, 20(5), 453-64. http://dx.doi.org/10.1002/(SICI)1098-240X(199710)20:5<453::AID-NUR9>3.0.co;2-N

Dinham, S., \& Scott, C. (2000). Moving into the third outer domain of teacher satisfaction. Journal of Educational Administration, 38(4), 379-96. http://dx.doi.org/10.1108/09578230010373633

Flanagan, N. A. (2006). Testing the relationship between job stress and job satisfaction in correctional nurses. Nursing Research, 55(5), 316-27.

Ganster, D. C., \& Perrewe, P. L. (2011). Theories of occupational stress. In J.C. Quick (Eds). Handbook of occupational health psychology $\left(2^{\text {nd }}\right.$ Ed., 37-53). Washington, D.C. American Psychological Association. 
Goddard, R. D. Hoy., W. K., \& Hoy, A. W. (2000). Collective teacher efficacy: its meaning, measure and impact on student achievement. American Educational Research Journal, 37(2), 479-507. http://dx.doi.org/10.3102/00028312037002479

Herzberg, F., Mausner, B., \& Synderman, B. (1959). Motivation and work. Wiley, New York: NY.

Kohn, T. P., \& Frazer, G. H. (1986). An academic stress scale identification rated importance of academic stressors. Psychological Reports, 59, 415-26. http://dx.doi.org/10.2466/pr0.1986.59.2.415

Kyriacou, C. (2001). Teachers stress: directions for future research. Educational Review, 53(1), 27-35. http://dx.doi.org/10.1080/00131910120033628

Lazarus, R. S., \& Folkman, S. (1984). Stress appraisal and coping. New York: Springer.

McCarthy, C. J., \& Lambert, R. G. (2006). Helping teachers balance demands and resources in an era of accountability. In R. Lambert and C. McCarthy (Eds.). Understanding teacher stress in an age of accountability. Greenwich, C.T : Information Age Publishing.

Miller, D., \& Fraser, E. (2000). Stress associated with being a student teacher: opening out the perspective. Scottish Educational Review, 32(2), 142-54.

Miller, M. D., Brownell, M. T., \& Smith, S. W. (1999). Factors that predict teachers staying in, or leaving or transferring from the special educational classroom. Exceptional Children, 65, 201-18. http://dx.doi.org/10.1177/001440299906500206

Mirowsky, J., \& Ross, C. E. (2000). Social causes of psychological distress ( $2^{\text {nd }}$ ed.). Hawthorne, NY: Aldine, De Greyther.

Pajares, F. (1996). Self efficacy beliefs in academic settings. Review of Educational Research, 66(4), 543-78. http://dx.doi.org/10.3102/00346543066004543

Perrachione, B. A., Roger, V. T., \& Peterson, G. T. (2008). Why do they stay? Elementary teachers perceptions of job satisfaction. The Professional Educator, 32(2), 25-41.

Ross, S. E., Niebling, B. C., \& Heckert, T. M. (1999). Sources of stress among college students. College Student Journal. 33(2), 312-18.

Rout, U. R. (2000). Stress amongst district nurses: a preliminary investigation. Journal of Clinical Nursing, 9(2), 303-9. http://dx.doi.org/10.1046/j.1365-2702.2000.00342.x

Sapolsky, R. M. (1998). Why zebras don't get ulcers? An update on stress, stress-related diseases and coping. New York: W.H. Freeman.

Schmidt, L. I., Sieverding, M., Scheiter, F., \& Obergfell, J. (2013). Predicting and explaining students' stress with the Demand-Control Model: Does neuroticism matter? Educational Psychology: An International Journal of Experimental Psychology, Heidelberg, Germany. http://dx.doi.org/10.1080/01443410.2013.857010

Skaalvik, E. M., \& Skaalvik, S. (2011). Teacher job satisfaction and motivation to leave the teaching profession: relations with the school context, feeling of balancing and emotional exhaustion. Teaching and Teacher Education, 27, 1029-1036. http://dx.doi.org/10.1016/j.tate.2011.04.001

Towbes, L. C., \& Cohen, L. H. (1996). Chronic stress in the lives of students: Scale development and prospective prediction of distress. Journal of Youth and Adolescence, 25, 199-217. http://dx.doi.org/10.1007/BF01537344

van der Doef., \& Maes, S. (1999). The job demand-control model and psychological well being: a review of 20 years of empirical research. Work and Stress, 13, 87-114. http://dx.doi.org/10.1080/026783779929296084 